\title{
NEW TRENDS IN THE MECHANISMS OF INCREASING PRODUCTIVITY OF MINERAL-BASED MATERIALS
}

\author{
T. N. Shchemelinina ${ }^{1}$, O. B. Kotova ${ }^{2}$, M. Harja ${ }^{3}$, E. M. Anchugova ${ }^{1}$, Y. Pelovski ${ }^{4}$ I. Cretescu $^{3}$ \\ ${ }^{1}$ Institute of Biology, Komi Science Center, Ural Branch of RAS; tatyanakomi@mail.ru \\ ${ }^{2}$ Institute of Geology, Komi Science Center, Ural Branch of RAS; kotova@geo.komisc.ru

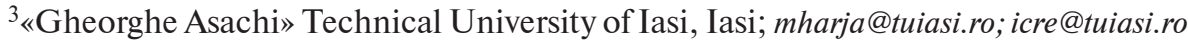 \\ ${ }^{4}$ University of Chemical Technology and Metallurgy, Sofia, Bulgaria; yonchop@gmail.com
}

Sorbents, proposed by the world industry to solve environmental problems, are not efficient enough for many technological parameters (selectivity, stability, etc.). It is necessary to search for mechanisms of increasing productivity of the sorption products. A new trend in the algorithm of modeling mineral-based materials is the isolation of strains and the development of new compounds that can improve their physical and chemical parameters. The objects of the research were lonsorb ${ }^{\mathrm{TM}}$ glauconite and immobilized strains of Pseudomonas yamanorum VKM B-3033D bacteria. We constructed a biosorbent and evaluated its sorption and destructive properties. The efficiency of purification from oil products with the help of the developed biosorbent in water reached $19 \%$ within 7 days, in ground $30 \%$ within 90 days.

Keywords: glauconite, biosorbent, adsorption, destruction, oil contaminated water, oil contaminated soil, railway bed, bacterial strain.

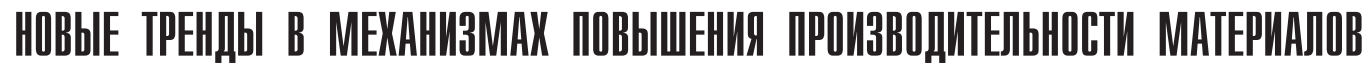 НА МИНЕРАЛЬНОЙ ОСНОВЕ}

\author{
Т. Н. Щемелинина ${ }^{1}$, О. Б. Котова ${ }^{2}$, М. Хария ${ }^{3}$, Е. М. Анчугова ${ }^{1}$, И. Пеловский ${ }^{3}$, И. Кретеску4 \\ ${ }^{1}$ Институт биологии Коми научного центра УрО РАН, Сыктывкар, Россия \\ ${ }^{2}$ Институт геологии Коми научного центра УрО РАН, Сыктывкар, Россия \\ ${ }^{3}$ Технический университет им. Г. Асаки, Яссы, Румыния \\ ${ }^{4}$ Университет химической технологии и металлургии, София, Болгария
}

\begin{abstract}
Сорбенты, предлагаемые мировой индустрией для решения экологических проблем, недостаточно эффективны по многим технологическим параметрам (избирательность, устойчивость и др.). Необходим активный поиск механизмов повышения производительности сорбционных продуктов. Новым трендом в алгоритме моделирования материалов на минеральной основе является выделение штаммов и разработка новых препаратов, способных улучшить их физикохимические показатели. Объектами исследования послужили глауконит lonsorb ${ }^{\text {тм }}$ и иммобилизованные на нем штаммы бактерий Pseudomonas yamanorum VKM B-3033D. Содержание остаточных нефтепродуктов в пробах определяли методом флуориметрии на анализаторе жидкости «Флюорат-02» в соответствии с ПНД Ф 16.1.21-98. В ходе работы был сконструирован биосорбент и дана оценка его сорбционных и деструктивных свойств. Эффективность очистки от нефтепродуктов с помощью разработанного биосорбента в воде составила до 19 \% за 7 суток, в грунте - до 30 \% за 90 суток.

Ключевые слова: глауконит, биосорбент, сорбция, деструкция, нефтезагрязненная вода, нефтезагрязненныйгрунт, штамм бактерий.
\end{abstract}

\section{Introduction}

The most common polluters of the territories of railway enterprises of different countries, including Russia, are oil, petroleum derivatives, masout, fuels, lubricants. The amount of contamination varies from 5 to $20 \mathrm{~g}$ per $1 \mathrm{~kg}$ of soil. The pollution of territories affects adversely the environment [1]. A natural self-purification of soils from oil pollution is a very long process that can last from one to several decades depending on the natural conditions of the region. Currently mainly mechanical and physical-chemical methods of oil removal are applied, which do not allow restoring the biocenosis without disturbing natural landscapes and additional harm to ecosystems. Therefore the bioremediation of soils is the most promising and maximally close to natural processes [1,3-6]. The remediation on the railway is considerably hampered by the fact the embankment is a sandy-gravel mixture and crushed stone. Therefore the actual cleaning solution will combine possible mechanisms of natural zeolites and microorganisms to increase the selectivity and productivity of sorption characteristics.

The aim of the work is to develop and evaluate the efficiency of the biosorbent for cleaning of contaminated soils on sections of the railway bed.

\section{Objects and methods of research}

The objects of our research were Ionsorb ${ }^{\mathrm{TM}}$ glauconite from the Bondarskoe deposit of Tambov region and Pseudomonas yamanorum VKM B-3033D bacterial strain isolated from the contaminated soil of the railroad bed near Syktyvkar City.

The total petroleum hydrocarbon (TPH) content in model water samples, contaminated and cleaned soil was analyzed fluorometrically on Fluorat-02 liquid analyzer according to PND F 16.1.21-98 [2].

\section{Results and discussion}

In the process of production of biological products the application of glauconite avoids the costly procedure of lyophilization for preserving microorganisms. Ionsorb ${ }^{\mathrm{TM}}$ acts as a sorbent of petroleum hydrocarbons, as well as a transport base for hydrocarbon-oxidizing bacteria, which allows them to be in suspended animation for up to 10 years. Glauconite is an aluminosilicate mineral, the cations are easily replaced by the excess elements in the surrounding medium. The layered structure of the mineral, its ion-exchange properties predetermine its high sorption properties to petroleum hydro- 
carbons, radionuclides and toxic elements. The ability of Ionsorb $^{\mathrm{TM}}$ to deposit water and low desorption rate immobilize the microorganisms and their metabolites on its surface. At that the rate of chemical bound reaction is such that the glauconite is able to bind pollutants for a short time, and the microbial community can conveniently utilize them. Another advantage of Ionsorb ${ }^{\mathrm{TM}}$ is that it increases the diffusion of oxygen and moisture in the soil, which provides optimal water, gas-air and thermal conditions for the growth of immobilized microorganisms. The activity of metabolic enzymes and the energy of all biochemical processes increase significantly. Since Ionsorb ${ }^{\mathrm{TM}}$ is a mineral fertilizer itself, it is not necessary to recycle biosorbent spent.

\section{Constructing a biosorbent}

The strain of $P$. yamanorum bacteria was grown in a bioreactor for 3-5 days under conditions of liquid phase fermentation at a temperature of $15-25^{\circ} \mathrm{C}$ until a cell titer of $10^{9} \mathrm{CFU} /$ $\mathrm{cm}^{3}$ was achieved on a medium of the following composition: per $1000 \mathrm{~cm}^{3}$ of water: peptone $-15 \mathrm{~g}$; $\mathrm{NaCl}-3.0 \mathrm{~g}$; $\mathrm{KCl}-$ $1.0 \mathrm{~g} ; \mathrm{MgSO}_{4} \times 7 \mathrm{H}_{2} \mathrm{O}-0.5 \mathrm{~g}$. The spray application of the strain on the sorbent was then carried out and dried at a temperature of $30-35^{\circ} \mathrm{C}$.

The composition of the biosorbent: glauconite $-85-$ $90 \%$, strain of $P$. yamanorum bacteria $-10-15 \%$.

To assess the efficiency of adsorption immobilization, the samples were analyzed with a scanning electron microscope VEGA3 TESCAN, ×5000 (see Figure 1).
Estimation of sorption and destructive properties of the biosorbent in a model water.

To study the sorption and hydrocarbon oxidation properties of the biosorbent obtained we performed an experiment with model water in the presence of crude oil and waste oil. For $1000 \mathrm{~cm}^{3}$ water we added: $\mathrm{NaNO}_{3}-5.0 \mathrm{~g} ; \mathrm{KH}_{2} \mathrm{PO}_{4}-$ $3.0 \mathrm{~g} ; \mathrm{KCl}-0.5 \mathrm{~g} ; \mathrm{MgSO}_{4} \times 5 \mathrm{H}_{2} \mathrm{O}-0.5 \mathrm{~g} ; 100 \mathrm{~cm}^{3}$ of the solution was poured into $250 \mathrm{~cm}^{3}$ flasks, autoclaved for $20 \mathrm{~min}$ utes, cooled to the room temperature. $0.5 \mathrm{~g}$ of crude oil or waste oil and $1 \mathrm{~g}$ of biosorbent were added to the flasks. In the reference variant the biosorbent was not added. The flasks were exposed in a shaker $(220 \mathrm{rpm})$ for 7 days under normal conditions. After 7 days the content of residual oil products was determined in the samples.

As can be seen from Table 1, when the biosorbent is added, the concentration of oil products is significantly decreased $(\mathrm{p}<0.05)$, in a contaminated medium by $13 \%$, in an oil-polluted medium - by $19 \%$, and these results indicate that the developed biosorbent possesses sorption and oil destructive properties and is suitable for further researches and model experiments on cleaning of contaminated soils.

Estimation of oil-oxidizing properties of the biosorbent in an oil-contaminated soil from the railway bed.

To study the possibility of application of the biosorbent developed to clean the contaminated soil of the railway bed, the laboratory simulation of the process was carried out. Strongly waste oil contaminated sand-gravel mixture (SGM) was taken from the section of the railway bed. Biosorbent with miner-

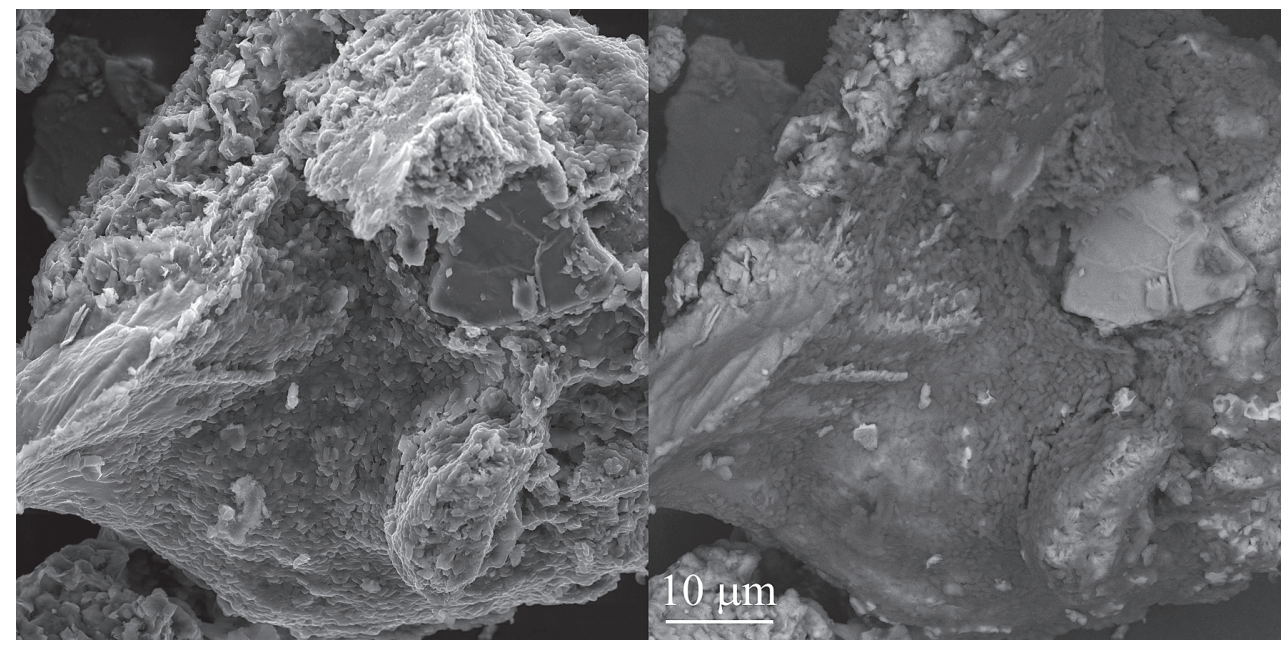

Ionsorb $^{\mathrm{TM}}$ surface with immobilized cells of strain Pseudomonas yamanorum VKM B-3033D.

The sample was microscopyed with Scanning Electron Microscope Tescan Vega 3 LMH. (operator Tropnikov E.M.)

Исследование состояния поверхности проводили с помощью сканирующего электронного микроскопа Tescan Vega 3 LMH (оператор Е. М. Тропников)

Table 1

TPH content in water samples after the application of biosorbent, $\mathrm{mg} / \mathrm{g}$

Таблица 1

Изменение концентрации нефтепродуктов в образцах воды в присутствии биосорбента, мг/г

\begin{tabular}{l|c}
\hline \multicolumn{1}{c|}{ Variant } & TPH content in samples after exposition, mg \\
\hline Reference (water medium + waste oil) & $431.0 \pm 13.61$ \\
\hline Medium + 0.1 g waste oil + 1 g biosorbent & $375.0 \pm 5.00^{*}$ \\
\hline \multicolumn{2}{|c}{} \\
\hline Reference (water medium + oil) & $384.0 \pm 11.53$ \\
\hline Medium + 0.1 g oil + 1 g biosorbent & $313.0 \pm 4.36^{*}$
\end{tabular}

Note: *- difference is accurate at $\mathrm{p}<0,05$. The accuracy of difference was estimated by comparison to the reference groups. 
TPH content in soil samples after the application of biosorbent, $\mathrm{mg} / \mathrm{g}$

Table 2

Таблица 2

Изменение концентрации нефтепродуктов в пробах грунта в присутствии биосорбента, мг/г

\begin{tabular}{l|c}
\hline \multicolumn{1}{c|}{ Variant } & TPH content in samples after exposition, mg \\
\hline Reference (water medium + waste oil) & $431.0 \pm 13.61$ \\
\hline Medium + 0.1 g waste oil + 1 g biosorbent & $375.0 \pm 5.00^{*}$ \\
\hline \multicolumn{2}{|c}{} \\
\hline Reference (water medium + oil) & $384.0 \pm 11.53$ \\
\hline Medium + 0.1 g oil + 1 g biosorbent & $313.0 \pm 4.36^{*}$
\end{tabular}

al fertilizers (NPK-15) in amount of $2.5 \mathrm{~g}$ was added to $300 \mathrm{~g}$ SGM sample. The samples were moistened and thoroughly mixed during the whole experiment.

The reference was oil contaminated SGM. Sampling for analytical studies was carried out after 3, 30 and 90 days.

Since glauconite has a finely dispersed structure, it is well distributed in the contaminated sand-gravel mixture.

The table shows that the TPH content decreased in SGM of all variants of the experiment in comparison to the reference. Within 3 days the sorption of the oil products after the application of the biosorbent occurs $(p<0.05)$ by $25 \%$. Within 30 and 90 days in the samples with the biosorbent without mineral fertilizers, the concentration of oil products is not changed (Table 2). Despite the fact that glauconite contains a significant amount of biogenic elements - labile potassium, phosphorus and microelements essential both to microbial and plant growth, a high soil contamination suppresses the growth of cells of immobilized bacteria. The adding of a mineral NPK fertilizer leads to the effective sorption and destruction of TPH with the biosorbent, and its efficiency reaches $(\mathrm{p}<0.05) 30 \%$ within 90 days (Table 2).

\section{Conclusions}

1. We constructed a biosorbent based on Ionsorb ${ }^{\mathrm{TM}}$ glauconite and strain of oil-oxidizing Pseudomonas yamanorum VKM B-3033D bacteria.

2. We determined the sorption and destructive properties of the biosorbent developed in oil-contaminated water and soil.

3. The efficiency of purification from $\mathrm{TPH}$ in water reached $19 \%$ within 7 days, in ground $30 \%$ within 90 days.

It is recommended to use the biosorbent developed to clean the soil of the railroad bed, as well as water ecosystems, of petroleum hydrocarbons.
The researches were carried out with the financial support of the State task «Technology of living systems» on the basis of higher plants, cultivated plant cells, microorganisms and enzymes for obtaining of biomedical products, biofuels and environmental protection» No. 115021210021 and BIOECOBALANS LLC.

\section{References}

1. Zubrev N. I., Sharpova N. A. Okhrana okruzhaiushchei sredy i ekologicheskaia bezopasnost 'na zheleznodorozhnom transporte (Environmental protection and environmental safety in railway transport). Moscow: UMK MPS of Russia 1999, 592 pp.

2. Metodika vypolneniia izmerenii massovoi doli nefteproduktov $v$ probakh pochv na analizatore zhidkosti «Fliuorat-02». (Methods of performing measurements of the mass fraction of petroleum products in soil samples on a Fluorat-02 fluid analyzer). Institute of Biology of Komi SC UB RAS, Moscow, 1998, 15 pp.

3. Nazarenko M. D., Romanova K. N., Lobanov V. G. Sposob vosstanovleniia neftezagriaznennykh pochvi gruntov (Method for the restoration of oil-contaminated soils and soils). Fundamentalnye issledovaniia, 2006, No. 8, pp. 32-33.

4. Rogozina E. A., Shimansky V. K. Nekotorye teoreticheskie aspekty vosstanovleniia neftezagriaznennykh pochvennykh ekosistem (Some theoretical aspects of the restoration of oil-contaminated soil ecosystems). Neftegazovaya Geologiya. Theory and practice, 2007, V. 2, 16 pp.

5. Kotova O. B., Harja M., Cretescu I., Noli F., Pelovski Y., Shushkov D. A. Zeolites in technologies of pollution prevention and remediation of aquation systems // Vestnik of Institute of Geology of Komi Sience Center of Ural Branch RAS. 2017. No 5. pp. 49-53. (doi: 10.19110/2221-1381-2017-5-49-53)

6. Soprunova O. B. Mikrobnye biotekhnologii remediatcii (ochistka) pochv, zagriaznennykh neftiu i nefteproduktami na territorii Atyrauskoi oblasti (Microbial biotechnologies of remediation (cleaning) of soils polluted with oil and oil products in the territory of Atyrau region). Molodoy ucheny, 2014, No. 20, pp. 41-43. 